\title{
A COMPREHENSIVE FRAMEWORK FOR COMPARING WATER USE INTENSITY ACROSS DIFFERENT TOURIST TYPES
}

Michalis Hadjikakou ${ }^{1,2 *}$, Graham Miller ${ }^{3}$, Jonathan Chenoweth ${ }^{2}$, Angela Druckman ${ }^{2}$, Christos Zoumides $^{4}$

1 Water Research Centre, University of New South Wales, Sydney, NSW 2052, Australia

2 Centre for Environmental Strategy, University of Surrey, Guildford, GU2 7XH, UK

3 School of Hospitality and Tourism Management, University of Surrey, Guildford, GU2 7XH, UK

4 Energy, Environment and Water Research Center (EEWRC), The Cyprus Institute, Nicosia 2121, Cyprus

\section{Principal author contact $(*)$ details:}

Dr. Michalis Hadjikakou

Position: Postdoctoral Research Associate

Full Postal Address: Water Research Centre, School of Civil \& Environmental Engineering, University of New South Wales, NSW 2051, Australia

Contact number: +61293854151

Email address: m.hadjikakou@unsw.edu.au

\section{Please cite article as:}

Hadjikakou, M., Miller, G., Chenoweth, J., Druckman, A. \& Zoumides, C. (2015): A comprehensive framework for comparing water use intensity across different tourist types, Journal of Sustainable Tourism, DOI: 10.1080/09669582.2015.1044753.

Published online: 30 Jul 2015

To link to this article: http://dx.doi.org/10.1080/09669582.2015.1044753 


\begin{abstract}
Tourism products vary in their direct and indirect (supply chain) water use, as well as their economic contribution. Hence, water-scarce destinations require a method to estimate and compare water use intensity (water use in relation to economic output) for different kinds of tourist products in order to optimise their tourism offering. The present study develops an original framework that integrates segmentation with an Environmentally Extended InputOutput (EEIO) framework based on detailed tourism expenditure data and Tourism Satellite Accounts (TSAs) in order to quantify the total (direct and indirect) economic impact and water use for multiple tourism segments. To demonstrate the rigour of the methodology it is applied to the eastern Mediterranean island of Cyprus as a case study. The results show that cheaper forms of tourism tend to have a significantly lower total water use and, depending on the economic impact indicator of interest, may have above-average economic contribution per unit of expenditure. The proposed framework provides a significant step towards achieving sustainable water use through destination-specific estimates of water use intensity which take into consideration segment-specific attributes. It is envisaged that this could eventually lead to customised interventions for diverse tourism market segments.
\end{abstract}

Keywords: environmental indicators; sustainable tourism; market segmentation; environmentally extended input-output; water footprint; environmental management

\title{
Introduction
}

The issue of water use by the tourism industry has been attracting considerable attention in recent years, as demonstrated by the theme for the 2013 World Tourism Day: "Tourism and Water". On this occasion, the United Nations World Tourism Organization's (UNWTO) Secretary General highlighted the value of water as one of tourism's most precious resources (UNWTO, 2013a). Despite the importance of water as an input, on paper tourism appears to have a negligible impact on global water resources, with published figures suggesting that international tourism accounts for less than one per cent of national water use in most countries (Gössling et al., 2012). However, water demand from tourism tends to be extremely concentrated in space and time (Essex, Kent, \& Newnham, 2004; Hadjikakou, Chenoweth, \& Miller, 2012). This can put considerable stress on local water resources, often accounting for a significant percentage of water use in places where tourism is an important economic activity (Gössling et al., 2012; Hadjikakou, Chenoweth, \& Miller, 2013).

This stress is set to increase: in addition to being one of the world's largest industries, generating more than 9.5\% of global GDP in 2013 (WTTC, 2014b), tourism is also one of the fastest-growing economic sectors, with new destinations constantly emerging and tourist arrivals worldwide expected to increase by an average of $3.3 \%$ per annum from 2010 to 2030 (UNWTO, 2013c). Recent publications on the topic of tourism water use in both academic (Cazcarro, Hoekstra, \& Sánchez Chóliz, 2014; Cole, 2014; Gössling et al., 2012; Hadjikakou et al., 
2013; Kasim, Gursoy, Okumus, \& Wong, 2014; Sun \& Pratt, 2014) and non-academic circles (Becken, Rajan, Moore, Watt, \& McLennan, 2013; Tourism Concern, 2012; UNEP-UNWTO, 2012) demonstrate the significance of the need to better quantify both direct and supply chain water consumption in the tourism sector. In order to do so, appropriate methodologies and relevant water use indicators that allow water-specific comparisons between different types of tourism, must be explored. This is a prerequisite for ultimately developing sustainable management solutions customised to specific tourism products in water scarce destinations.

Given tourism's undeniable role in generating economic output and supporting livelihoods in many parts of the world, efforts to sustainably use water must ideally be geared towards maintaining or even increasing industry profits. Comprehensive methodologies for quantifying water use should therefore incorporate both environmental and economic impact indicators. The argument for minimising environmental impacts whilst maintaining high economic benefits is prominent in recent sustainable tourism literature. The concepts of eco-efficiency (Becken \& Patterson, 2006; Gössling et al., 2005) and sustainable yield (Becken \& Simmons, 2008; Lundie, Dwyer, \& Forsyth, 2007; Northcote \& Macbeth, 2006) have succeeded in advancing the traditional economic measures of tourism yield to account for environmental impacts, including water use (Lundie et al., 2007; Sun \& Pratt, 2014).

Developing water-specific yield approaches is particularly relevant and timely for water scarce destinations and, in particular, established tourism destinations looking to diversify their product base. In the last decade there has been much talk of upgrading or diversifying tourism in the Mediterranean (Bramwell, 2004; Rico-Amoros, Olcina-Cantos, \& Sauri, 2009), an area traditionally associated with 'sun and sand' mass tourism, with the purpose of maximising tourism revenue. Recent studies suggest that the luxury end of the tourism market uses considerably more water, mainly as a result of its reliance on water-intensive facilities (Hof \& Schmitt, 2011; Rico-Amoros et al., 2009; Tortella \& Tirado, 2011). However, these studies consider only direct water use and do not include any economic impact estimates.

The primary aim of the present research is to contribute towards addressing this methodological gap. Using an environmentally extended input-output (EEIO) (Leontief, 1970) framework which combines tourism satellite account (TSA) data and alternative market segmentation techniques, the study develops a novel approach to comprehensively estimate and subsequently compare total water consumption and economic impact of different tourist types in a Mediterranean island. A secondary aim is to critically assess the potential of the approach to generate insightful context-specific policy implications.

\section{Quantifying tourism water use using the notion of water use intensity}

The notion of generating more economic and societal utility using less water is irrefutably attractive (Gleick, 2003). One of the challenges in the case of tourism is that it is a highly diverse industry, offering a plethora of products that cater for different tastes and budgets at different 
times of the year. These products differ in terms of the economic impact they generate, and also in terms of the quantity of water they necessitate. There is therefore a need to use environmental-economic indicators that capture this heterogeneity.

The concepts of water use intensity, 'economic water productivity', eco-efficiency and sustainable yield all provide a potential basis for creating water use indicators that can be used to compare different types of tourism. Water use intensity, like eco-efficiency or sustainable yield, measures resource use per unit of economic output (for the case of water, $\mathrm{m}^{3} / \$$ ) (UNESCO, 2009). Economic water productivity, on the other hand, expresses economic output per unit of water use (for example, $\$ / \mathrm{m}^{3}$ ) (Gleick, 2003). The UN DESA (2007) recommends water use intensity for identifying the most relevant economic activities for tourism. Additionally, the concept of water use intensity is consistent with previous work on tourism, where the rationale is to minimise resource consumption per unit of economic output (Becken \& Simmons, 2008; Gössling et al., 2005; Lundie et al., 2007). For this reason, the present study considers several different indicators of water use intensity.

Comprehensive estimates of water use intensity require quantification of the total (direct and indirect) contribution of tourism to the economy and comparing this to the total (direct and indirect) water demand from the sector. The methodological challenge is that tourism is characterised by a large number of indirect and induced linkages to other economic sectors in the form of purchases of many diverse products from these sectors (Briassoulis, 1991). Quantifying the economic and resource use impacts of tourism consumption necessitates detailed information on these linkages. These economic linkages also disperse water demand to several other sectors that cater for tourism purchases, activities, infrastructure and meals.

Earlier studies on water and tourism focused solely on direct (onsite) water use in tourist facilities such as hotels, golf courses and swimming pools (Essex et al., 2004; Gössling, 2001). Given tourism's global extent, however, tourism management has an immediate obligation to look beyond direct water use (Gössling et al., 2012). The 'virtual' (or embedded) water (Allan, 1998) and 'water footprint' (Hoekstra, 2003) concepts have highlighted how the majority of water consumption takes place in the supply chain of agricultural and industrial products. Owing to its long supply chain and high dependency on food and other goods and services, tourism consumption consequently has a substantial overall impact on total water use in water scarce regions, frequently far outweighing direct water use (Cazcarro et al., 2014; Gössling et al., 2012; Hadjikakou et al., 2013; Sun \& Pratt, 2014). This is not to say that ongoing efforts to minimise direct water use in tourism facilities are unimportant, but that these should not be pursued at the expense of reducing water use intensity along the entire tourism supply chain.

The discussion thus far has highlighted the need for specialised frameworks to quantify total (direct and indirect) tourism water use within an economy that can also be used to compare water use intensity between tourist types with different economic contributions (e.g. mass tourism vs. luxury tourism). Munday et al. (2013) provide a compelling argument in favour of 
'consumption-based accounting1' methods such as EEIO to concurrently estimate the environmental and economic impacts of tourism consumption. Several tourism studies have successfully used variants of EEIO to estimate environmental-economic impacts of tourism consumption in different settings (Cazcarro et al., 2014; Jones \& Munday, 2007; Lundie et al., 2007; Munday et al., 2013; Sun \& Pratt, 2014; Sun, 2014).

Lundie et al. (2007), Cazcarro et al. (2014), and Sun \& Pratt (2014) are, to our knowledge, the only previous tourism-related studies which explicitly quantify total water use with EEIO frameworks. Lundie et al. (2007) estimate water use along with energy use, greenhouse gas emissions and ecological footprint for different tourism niche markets in Australia, in an attempt to establish trade-offs between economic and environmental objectives of tourism policy. Their results show that tourism markets with high daily expenditure also appear to have the highest environmental impact. Cazcarro et al. (2014) use a highly disaggregated inputoutput model to estimate tourist water footprints in Spain, offering a detailed breakdown of direct and indirect (from both local and imported products) water use. They conclude that in order to maximise potential water savings, the tourism industry should aim to reduce the quantity and water intensity of inputs used directly or indirectly in the production of tourist goods and services. The latest tourism EEIO study is Sun \& Pratt (2014), who estimate ecoefficiency in terms of carbon and water use intensity for Chinese tourists in Taiwan, and compare this to four other major country markets. Their results show that Chinese tourists have a higher water use intensity compared to other tourists, mainly due to high expenditure on food products.

The present study is significant because it builds on the three aforementioned water-related EEIO studies by adding novel elements in order to create more insightful water use intensity indicators. Firstly, segmentation and yield estimation are treated as part of an integrated framework, as the way in which tourist types are defined plays a crucial role when performing water use intensity comparisons. This integration is only previously seen in Becken et al. (2003) and also provides a follow-up to AUTHORS (DATE) who emphasise the need for market segments that go beyond country of origin distinctions between tourists. Secondly, whilst the universal indicator for water use impact is the volume of water used, there are numerous possible indicators for economic impact expressed in both monetary and non-monetary terms (Dwyer \& Forsyth, 2008; Pratt, 2012). A further contribution of the study is to explore alternative water use intensity indicators which consider economic value added and employment generation along the whole tourism supply chain. The result is a rigorous, original

\footnotetext{
${ }^{1}$ The consumption accounting principle (CAP) attributes resource use or emissions to the end consumer irrespective of the origin of products or services (Sun, 2014). By contrast, the production accounting principle (PAP) attributes all resource use or emissions to the producing region. According to Munday et al. (2013) and Sun (2014), the ideal accounting principle for capturing all carbon emissions associated with aviation lies in between the PAP and the CAP. This argument does not apply to water accounting where CAP is the appropriate accounting principle (as seen in Cazcarro et al., 2014).
} 
and versatile tool able to select the most useful segmentation and water use intensity indicators in different destinations.

\section{Methods}

\section{Case study destination}

The Republic of Cyprus (hereinafter 'Cyprus') in the eastern Mediterranean is chosen as the case study destination. Cyprus is an ideal choice for a number of reasons.

Firstly, it is a popular destination, with tourism established as the dominant economic sector since the early 1980s. In 2013, around 2.4 million international tourists visited Cyprus - almost three times the resident population of 860,000 (based on the 2011 census) (CYSTAT, 2014). In the same year, the tourism sector made an estimated total contribution of $20.6 \%$ to GDP and supported $22.1 \%$ of total employment (WTTC, 2014a).

Secondly, Cyprus is considerably water scarce. With an average annual precipitation of around $460 \mathrm{~mm}$, the climatic regime is classified as semi-arid, making it one of the European Union (EU) member states experiencing the highest levels of water stress (Hochstrat \& Kazner, 2009). As in other Mediterranean islands, water demand can often exceed natural water availability during the summer months, as this is when most tourists visit and is also a time when natural flows are lacking. Future water availability is expected to be severely affected by climate change, since the eastern Mediterranean region is considered to be an extremely sensitive 'hotspot' (Ludwig, Roson, Zografos, \& Kallis, 2011).

Thirdly, Cyprus, traditionally a 'sun and sand' resort particularly popular with British tourists, is currently attempting to upgrade its product base. The government and the tourism sector alike are eager to diversify the tourism product in order to attract higher-spending clientele (Adamou \& Clerides, 2009).

Finally, Cyprus is a small island nation and a member of the EU. The small geographic area $\left(9250 \mathrm{~km}^{2}\right)$ means that the need to account for inter-regional differences is minimised. The economic importance of the tourism sector, along with its EU membership, also means that Cyprus has comprehensive data on tourism, including TSAs ${ }^{2}$. With the current economic downturn in the EU and the recent collapse of Cyprus as an offshore banking centre, the President of the country has stressed the importance of tourism to the economy (UNWTO, 2013b). The present study is therefore a timely attempt to comprehensively quantify the total (direct and indirect) water consumption of the tourism sector, and to compare water use intensity between different tourist types typically present on the island.

\footnotetext{
2 TSAs are satellite accounts of the core national accounts compiled from visitor expenditure data, industry data, and supply and use relationships in the System of National Accounts (Dwyer, Forsyth, \& Dwyer, 2010).
} 


\section{Methodological framework}

Figure 1 provides a generalised illustration of the framework employed in the present study and suggested as a blueprint for future tourism EEIO studies. The framework consists of: (a) establishing market segments whose water use (or other resource use) intensity is to be subsequently compared, (b) collecting and harmonising the different types of environmental and economic data required to run the EEIO model and (c) running the EEIO model to estimate total environmental and economic impact for each tourist segment. Each step is subsequently elaborated, using data specific to the present case study.

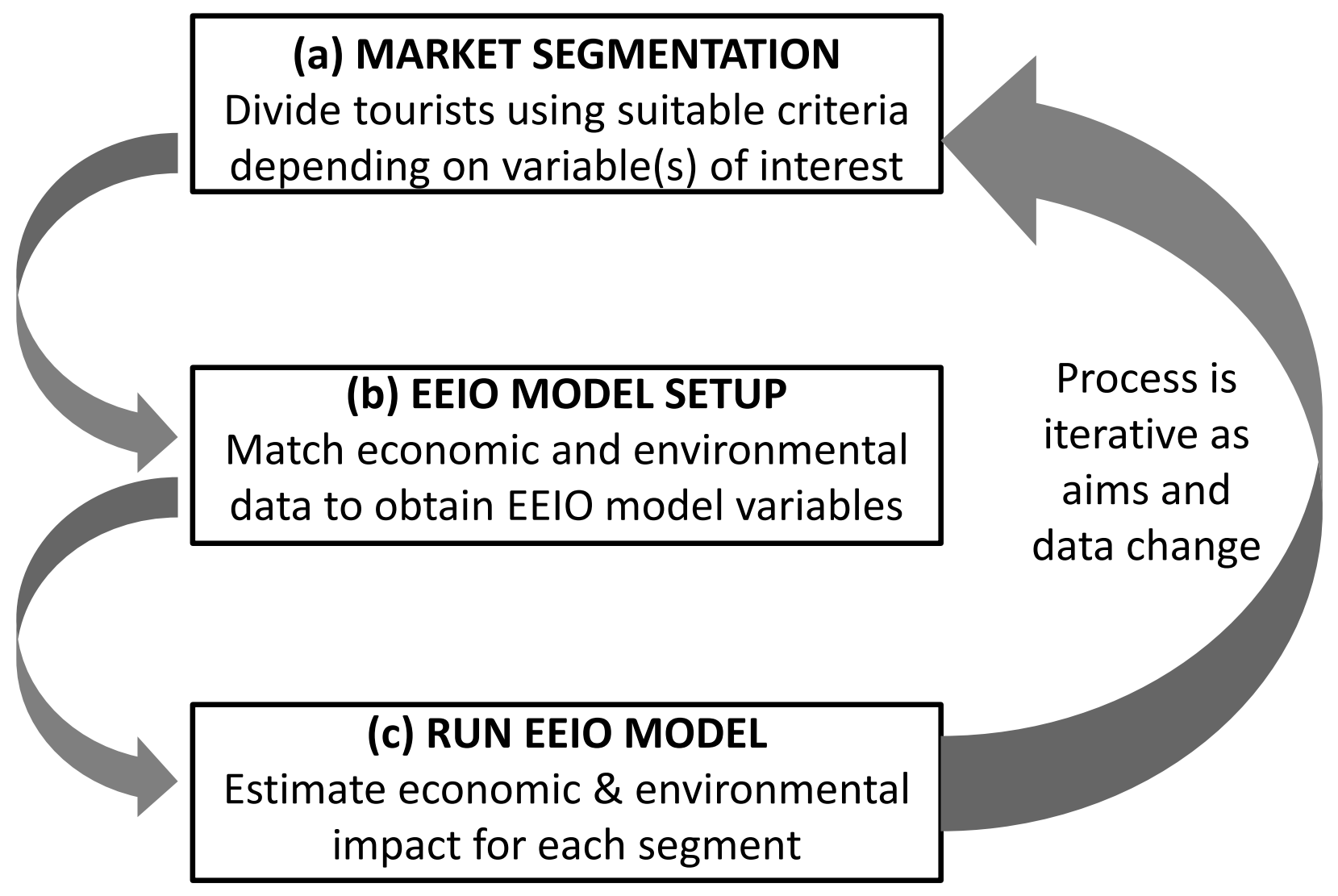

Figure 1 Simple illustration of the three-stage framework highlighting its potential to be used iteratively for updating and refining the analysis.

\section{(a) Market segmentation}

The Cyprus Tourism Organisation (CTO) only differentiates tourists based on their country of origin (COO), which is usually the basis for collecting and interpreting tourism data (Reid \& Reid, 1997). However, AUTHORS (DATE) have recently argued that existing COO market segments do not accurately capture differences within large country markets. In the case of Cyprus, grouping and targeting all UK tourists who accounted for $37-57 \%$ of annual inbound tourism in the period 2005-2012 (CYSTAT, 2014), overlooks the considerable heterogeneity within this important market segment. In order to better appreciate the factors that influence 
water use and water use intensity, it is necessary to consider alternative options of segmentation based on tourist characteristics and consumption patterns rather than on nationality.

The process of 'tourism market segmentation' (UNWTO, 2007) should be seen as an integral first step in studies in which the objective is to compare the economic and environmental impacts (including but not restricted to water use) of different tourist types. Depending on the kind of comparison sought, multiple appropriate segmentation criteria may need to be tested. This is illustrated by the potential of the framework to operate iteratively, although this was not performed in the present study (Figure 1).

The market segments considered here were recently published in AUTHORS (DATE) using a large passenger survey dataset from the Cyprus Statistical Service (CYSTAT) consisting of 30,849 completed questionnaires from 2007. The following market segments are included:

- The average inbound tourist and the main country markets for Cyprus (UK, Russia, Germany, Sweden and Greece). This provides an established mode of comparison between different tourists and also acts as the first layer of segmentation necessary before forming sub-segments of the UK country market.

- Three expenditure-based sub-segments of the UK country market: low spending, medium-spending and high-spending tourists. This provides an idea of how total expenditure influences water use and economic contribution, and can be used to ascertain whether or not a higher expenditure produces enough economic impact to compensate for the potential increase in direct and indirect water use.

- Three sub-segments of the UK country market established using data-driven segmentation (see Dolnicar, 2008) based on socio-demographic and behavioural visitor characteristics: 'luxury tourists', 'average non-package' and 'budget mass tourists' (AUTHORS, DATE). Despite some similarity with the expenditure-based segments, this type of segmentation provides an example of how a host of factors other than expenditure, such as the purpose of the trip or the type and location of accommodation, affect water use and economic impact.

\section{(b) Data harmonisation in relation to model set-up}

EEIO analysis is a top-down environmental accounting method that allows the association of economic accounts with environmental accounts of resource use or pollution. It is based on the input-output (IO) model (Leontief, 1936) that makes use of sectoral monetary transactions to account for interdependencies between industries in modern economies. The fundamental starting point in performing an IO analysis is information on the flows of products from each economic sector to each of the other sectors (Miller \& Blair, 2009). This is typically available in the form of an input-output table (IOT) of the economy. Most statistical agencies regularly produce IOTs as part of their System of National Accounts (SNA). 
The starting point for deriving the Leontief input-output model is to replace the inter-sectoral flow terms (denoted by $z$ ) with technical coefficients, interpreted as the monetary input value per monetary unit of output for each sector, described using the ratio:

$$
a_{i j}=\frac{z_{i j}}{x_{j}}
$$

The basic Leontief model is then based on the economic principle that total output $(\mathbf{x})$ is equal to intermediate demand plus final demand, given by:

$$
\mathbf{x}=\mathbf{A x}+\mathbf{y}
$$

where $\mathbf{A}$ is the 'direct requirements matrix' whose elements are all the technical coefficients ( $a$ in equation 1) for a given economy, and $\mathbf{y}$ is the vector of sectoral final demand. $\mathbf{y}$ can correspond to final demand from any group of consumers such as households, exports or, as performed in the present study, tourists. $\mathbf{x}$ is the vector of sectoral total outputs. Equation 2 is finally rearranged in terms of $\mathbf{x}$ :

$$
\mathbf{x}=(\mathbf{I}-\mathbf{A})^{-1} \mathbf{y}
$$

where $\mathrm{I}$ is an identity matrix $\mathbf{x}^{3}(\mathbf{I}-\mathbf{A})^{-1}$ is the 'Leontief inverse' matrix which captures an infinite sequence of additions into a single matrix inverse, ensuring that IO analysis can cover all supply chains at an infinite length (Murray \& Lenzen, 2010). $\mathbf{x}$ thus represents the total production (output) generated by each economic sector in order to satisfy final demand $(\mathbf{y})$ in the economy.

EEIO uses an extended IO model that combines economic and environmental data in order to incorporate environmental externalities (Leontief, 1970). It makes use of the Leontief inverse (equation 3), allowing both direct and indirect environmental pressures (resource use or pollution) corresponding to a given final demand ( $\mathbf{y}$ ) to be estimated. In addition to the total environmental impact, EEIO is can also trace the origin and destination responsible for the impact. This may be carried out from a variety of perspectives: per sector, per product, or correlated to the use of a natural resource. Common applications of EEIO include carbon emissions (Druckman \& Jackson, 2009), ecological footprint considerations (Wiedmann, Minx, Barrett, \& Wackernagel, 2006) and water use (Lenzen \& Foran, 2001; Zhao et al., 2011).

The basic EEIO approach requires estimation of direct impact coefficients for each economic sector (denoted by the vector $\mathbf{w}$ for water use in this case). This is a vector of resource use per unit of output for each sector within the IO framework, calculated as:

${ }^{3} I$ is a matrix with the same dimensions as A, with ones on the main diagonal and zeroes elsewhere. 


$$
\mathbf{w}=\frac{\mathbf{e}}{\mathbf{x}}
$$

where $\mathbf{e}_{\mathbf{i}}$ is a vector of water use (in $\mathrm{m}^{3}$ ) by each economic sector or commodity and $\mathbf{x}_{\mathbf{i}}$ is the previously defined vector of total sector output. The generalised expression for calculating the total water use for any given final demand vector is given by:

$$
W_{T}=\mathbf{w}(\mathbf{I}-\mathbf{A})^{-1} \mathbf{y}+W_{d}
$$

where $W_{T}$ stands for total water use, and $W_{d}$ corresponds to direct onsite water use (in the case of tourism, this refers to water use in places of accommodation), which needs to be added separately since it is not contained in the Leontief inverse.

Through the addition of imports into the IOT, EEIO can also distinguish between embedded water that originates from domestic sources and that which is imported from abroad. Cyprus is a small nation where many products consumed by tourists and residents are imported, implying that significant amounts of water are also imported 'embedded' in these products. The simple single-region model described in equation 5 must therefore be expanded to account for trade. There are several ways to achieve this, depending on the quality of data available and the objectives of the study. The present study uses the two-region Proops et al. (1993) framework and the 'domestic technology assumption' (DTA $)^{4}$ to overcome the absence of information on the water (resource) intensity and economic structure of the rest of the world. Equation 5 is therefore refined as follows:

$$
\begin{gathered}
W_{T}=\mathbf{w}\left(\mathbf{I}-\mathbf{A}_{\mathbf{1}}\right)^{-1} \mathbf{y}^{\mathbf{1 1}}+\mathbf{w}\left(\mathbf{I}-\mathbf{A}_{\mathbf{1}}\right)^{-1} \mathbf{B}_{\mathbf{2 1}}\left(\mathbf{I}-\mathbf{A}_{\mathbf{1}}\right)^{-1} \mathbf{y}^{\mathbf{1 1}} \\
+\mathbf{w}\left(\mathbf{I}-\mathbf{A}_{\mathbf{1}}\right)^{-1} \mathbf{y}^{\mathbf{2 1}}+W_{d}
\end{gathered}
$$

where $\mathrm{W}_{\mathrm{T}}$ refers to total water use, $\mathbf{A}_{1}$ is the domestic 'direct requirements matrix' for Cyprus, $\mathbf{B}_{21}$ is the import matrix of products from the rest of the world to Cyprus, $\mathbf{y}^{\mathbf{1 1}}$ is the final demand for domestic products, $\mathbf{y}^{21}$ is the final demand for imported products and the rest of the terms remain as defined in equations $1-5$.

The variables $\mathbf{w}, \mathbf{A}_{1}, \mathbf{y}^{11}, \mathbf{y}^{21}, \mathbf{B}_{21}$ and $W_{\mathrm{d}}$ in Equation 6 dictate the data requirements of the EEIO framework. In terms of environmental data, the framework requires sectoral water use data $\left(w_{\mathrm{i}}\right)$ as well as data from household and tourist accommodation $\left(W_{\mathrm{d}}\right)$. The economic data required are input-output tables (IOTs) from which to estimate $\mathbf{A}_{1}$ and $\mathbf{B}_{21}$ and TSAs from which to derive $\mathbf{y}^{\mathbf{1 1}}$ and $\mathbf{y}^{\mathbf{2 1}}$ for each tourist segment.

The Cyprus Water Development Department (WDD) (2011) provides estimated water consumption (in $\mathrm{m}^{3}$ ) for different sectors of the economy. Sectoral water use (e in equation 4 ) allows the calculation of $\mathbf{w}$. The WDD also provides information on domestic water use $\left(W_{\mathrm{d}}\right)$ for households, estimated at 217 litres per capita per day (WDD, 2011). For tourists, the

\footnotetext{
${ }^{4}$ This assumes that the virtual water content of imported goods is equal to that of equivalent local goods.
} 
segmentation data from step (a) on area and accommodation type and class for each segment were used to derive spatially- and temporally- specific water use figures for tourism accommodation from Savvides et al. (2001). This provides segment-specific $W_{\mathrm{d}}$ values.

As Cyprus does not currently release its own official IOTs, the study uses an IOT for Cyprus from the free online World Input-Output Database (WIOD) (Timmer et al., 2012). The WIOD IOT is a square 35 by 35 matrix. The decision to use the WIOD IOT was taken following a comparison of sectoral value added, total intermediate inputs and gross output for the period 2005-2009 against the Cyprus National Accounts (CYSTAT, 2012), to ensure its consistency. The WIOD IOTs are used to estimate $(\mathbf{I}-\mathbf{A})^{-1}, \mathbf{B}_{\mathbf{2 1}}$ and also to give the values for $\mathbf{y}^{\mathbf{1 1}}$ and $\mathbf{y}^{\mathbf{2 1}}$ for Cypriot households, which are used as a basis for comparison with the tourist segments.

In order to then estimate $\mathbf{y}^{\mathbf{1 1}}$ and $\mathbf{y}^{\mathbf{2 1}}$ for the tourist segments, it was necessary to use the latest edition of the Cyprus TSAs for 2003-2007. This first allowed matching the expenditure patterns of the segmented groups ${ }^{5}$ to those of the TSA classification following the procedure described in AUTHORS (DATE). The 'production accounts table' in the TSAs was subsequently used to distribute the initial expenditure into economic sectors which closely match those of the IOT classification. APrice base conversions from purchasers' prices into basic prices were performed using additional data from the Cyprus National accounts, and all final demand vectors were converted to 2007 USD prices using exchange rates provided by the WIOD (Timmer et al., 2012) to match the IOTs. Appendix 2 shows the TSA to IOT final demand ratios along with the price base conversion coefficients and relative shares of imports and local production for each IOT sector.

All environmental and economic data used in the framework are for the year 2007, which corresponds to the latest edition of the Cyprus TSAs. The use of slightly dated economic data is common in tourism EEIO studies as these require several matching datasets rarely produced on an annual basis (see, for example, Munday et al., 2013 and Sun \& Pratt., 2014).

\section{(c) Estimating and comparing water use and total economic impact for each tourist segment}

The analysis stage aims to, firstly, explore water use variations (in terms of total direct and indirect water use) between different tourist groups and, subsequently, differences in their water use intensity as well as trade-offs in different indicators. The following indicators of total (direct and indirect) economic contribution have been estimated using the EEIO model in the present study:

The objective of the analysis stage was to produce a wealth of comparison data that allows, firstly, an understanding of water use variations (in terms of total direct and indirect water use) between different tourist groups and, subsequently, differences in their water use intensity as

\footnotetext{
${ }^{5}$ Expenditure comprised of the following expenditure categories (sectors): transport, accommodation, food and drink, clothing and footwear, health, communications, culture and recreation, and other.
} 
well as trade-offs across selected indicators. The following indicators of economic impact are employed the present study.

Total gross value added (GVA in USD). This is defined as the value of output less the value of intermediate consumption (OECD, 2001). The total GVA in an economy plus taxes and minus subsidies on products is equal to gross domestic product (ONS, 2013). GVA per sector is given in the IOT.

Total employment contribution as number of full-time jobs equivalent (FTE). This is the number of jobs in the economy directly or indirectly supported by tourist spending. It is chosen to complement GVA because it is a non-monetary indicator with stronger social welfare implications. Furthermore, economic sectors with a high GVA do not necessarily employ many people. The WIOD provides estimates of employment per sector based on the Cyprus National Accounts.

Total GVA per American dollar (USD) of initial expenditure - This is a more composite indicator which allows for an appreciation of the GVA generated per dollar of expenditure. It is dependent on the pattern of expenditure as opposed to the total sum of expenditure. This indicator has previously been used in Salma \& Heaney (2004), but the current study is the first to relate this to water use per tourist segment.

Total employment contribution per million USD of initial expenditure - Similarly to the above, this allows for an estimation of the number of jobs generated for each million USD spent, and has previously been used in Salma \& Heaney (2004) and Dwyer et al. (2010). This is now related to water use in the present study.

\section{Results and analysis}

This section firstly presents selected findings in order to illustrate differences in water consumption between conventional COO markets before considering expenditure-based and cluster analysis-derived UK sub-segments. It then considers water use intensity across all COO and UK segments as a means to exploring the diverse impacts arising from different degrees of overall spending and forms of tourism.

\section{COO markets total water use}

Figure 2 shows a considerable range in daily water use between tourists and households, with the average tourist consuming almost twice as much water (1426 1) as the average Cypriot resident (7191). Direct water use accounts for $17-25 \%$ of total water use by tourists, with indirect water use accounting for $75-83 \%$. Local indirect water use makes up to $36-41 \%$ of total water use, with imported water making up $39-42 \%$. Slight variations between country markets are related to differences in spending patterns. When direct water use (all of which is local) is also 
considered, local water use accounts for $59-61 \%$ of the total, implying that well over half the water consumed is from within Cyprus.

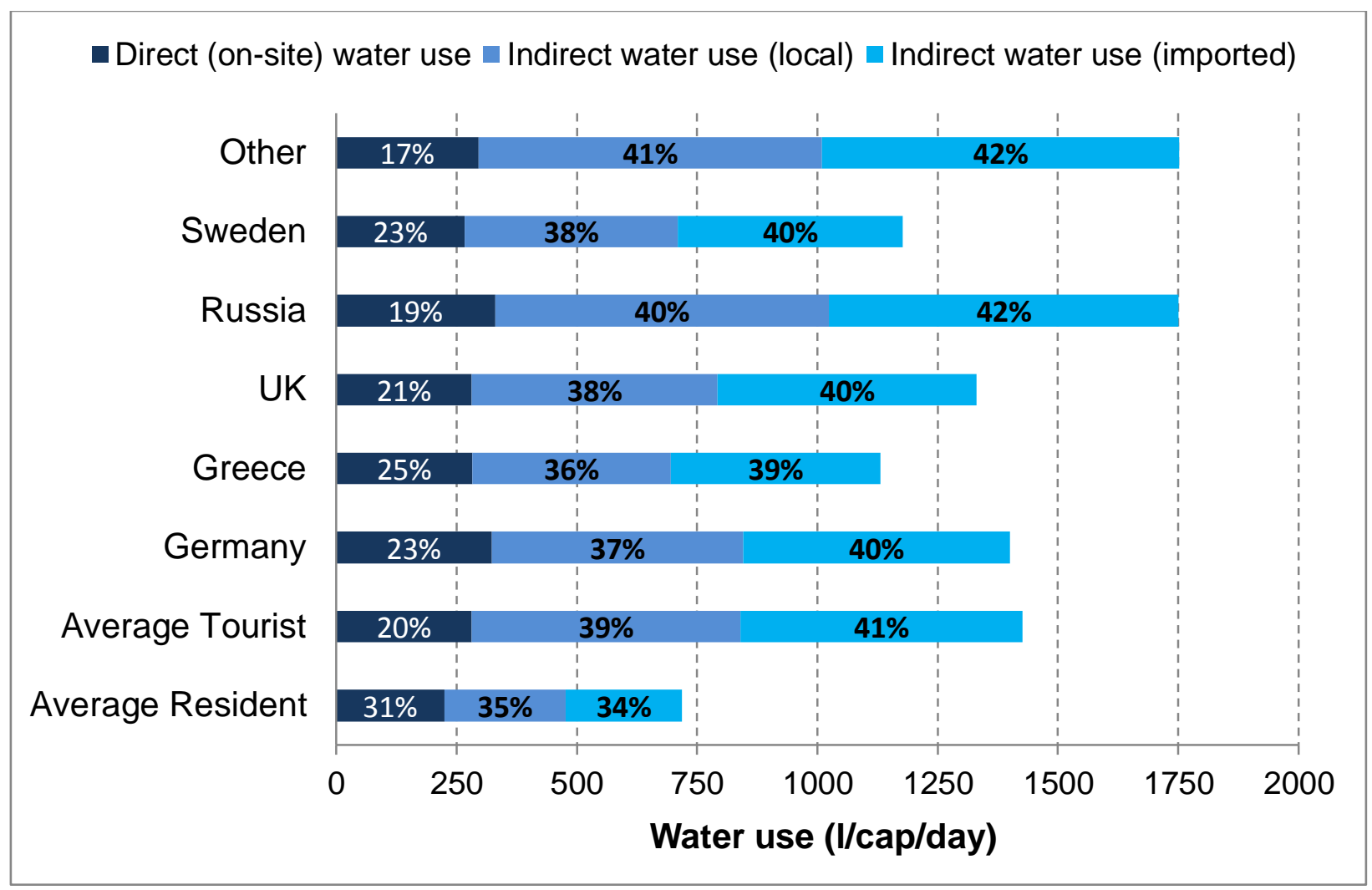

Figure 2 Daily direct and indirect water for the main country markets, the average tourist and households.

\section{UK segment total water use}

Figure 3 shows that there is considerably more variation in daily per capita water use (892-2142 $1 /$ cap/day) within the UK tourism segment than between the different country segments (Figure 2). This shows that considerable heterogeneity is lost when only considering different country segments. Segments that spend the most money ('luxury' and 'high-spending') are the ones associated with the highest total water use, with both of these segments consuming around three times as much water as an average Cypriot resident.

The relative contribution of direct and indirect (local or imported) water use also shows considerable variability, as highlighted in a comparison between the two extremes within the UK market. In the 'luxury' segment, $87 \%$ of total water use comes from the supply chain (43\% 
of which is local and $45 \%$ of which is imported), with only $13 \%$ of water being directly used onsite. In contrast, in the 'package' segment, $70 \%$ of total water use comes from the supply chain (34\% of which is local and $36 \%$ of which is imported), with $31 \%$ of total water use taking place on-site. Thus, even though on-site water use in absolute terms does not differ widely between the two segments, overall water use is around double in the 'high-spending' segment, owing largely to higher spending to buy food and other goods that require significant inputs of water in their production.

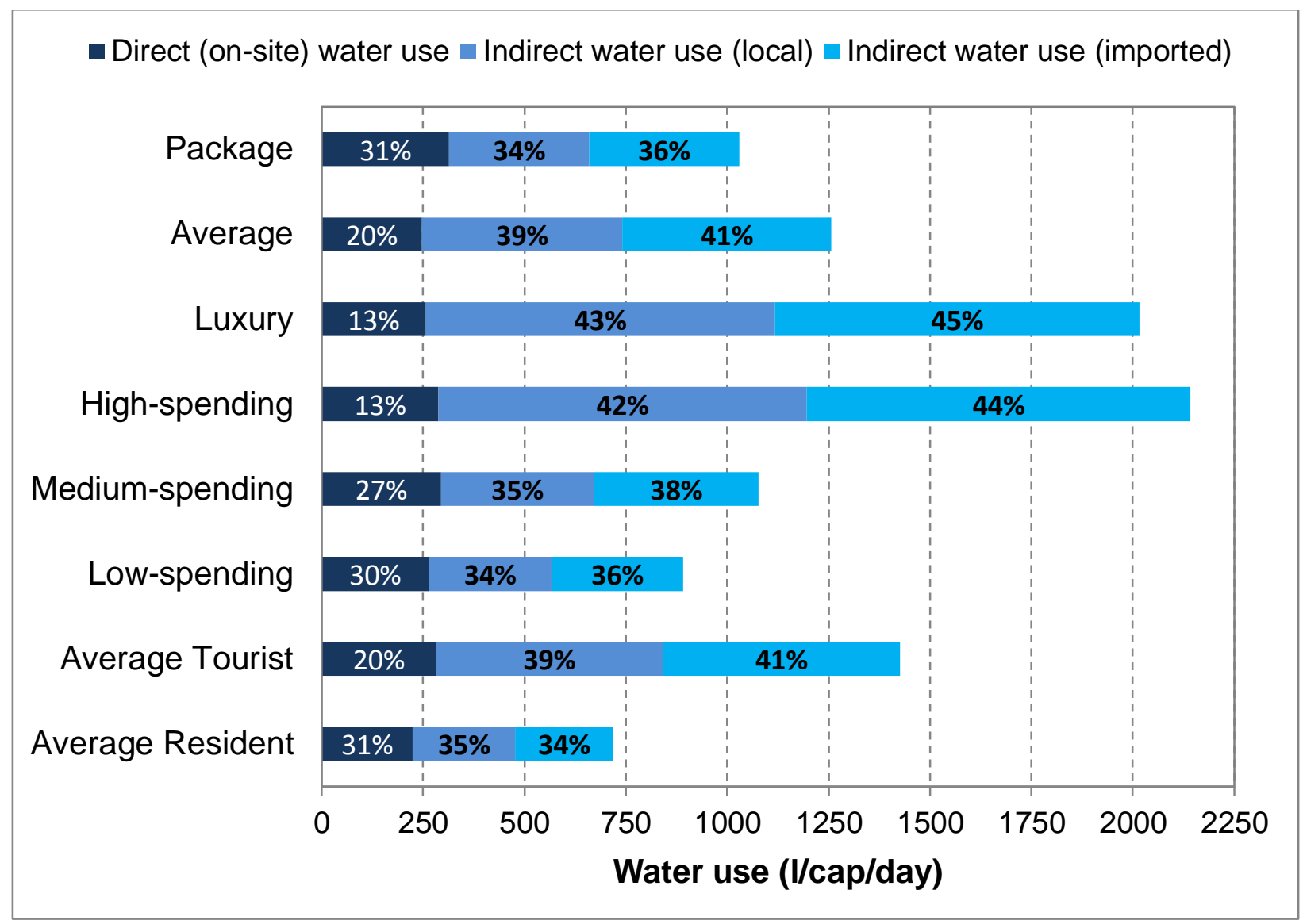

Figure 3 Daily direct and indirect water for different segments of the UK market.

\section{Water use intensity indicators - all segments}

Figure 4 shows that an average tourist uses 10.6 litres for every USD of total value added generated. This is significantly less than the average Cypriot resident, who requires 17 litres in order to generate one USD of value added. This suggests that, even though tourists use significantly more water than local residents, they do contribute considerably more to the economy. It therefore becomes more important to explore the range of values for different tourist types. Once again, taking two extremes as an example, the 'package' segment requires 12.1 litres (14\% more than the average tourist) for every USD of value added generated whereas 
the 'luxury' segment requires only 9.7 litres ( $8 \%$ less than the average tourist) for every USD of value added. These seemingly small differences in water use intensity per USD become substantial when multiplied by total expenditure per tourist over an entire trip.

It is evident that the higher-spending tourist segments ('luxury' and 'high-spending') tend to generate more value added for each litre of water they use. Tourists from Greece, Russia, and countries other than the five included (hereafter 'Other') also require less water than average (10.6 1 per USD value added) for every USD of value added generated. In the case of Russia and Other this is to be expected as both have high value added contributions (see Table 1). Greece on the other hand, is a slightly surprising result, as this country segment has a low per capita

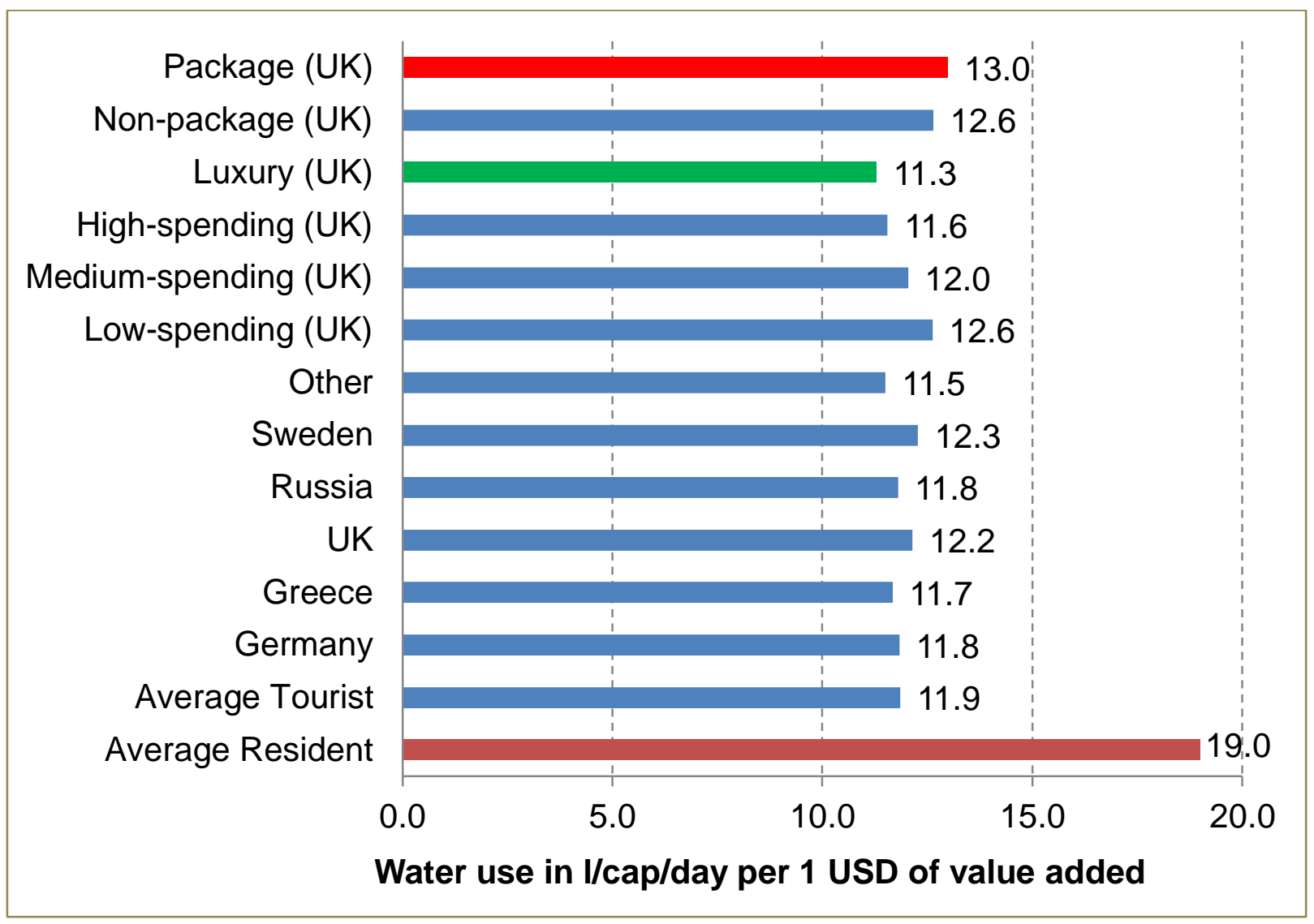

Figure 4 Water use intensity for all tourist segments and residents.

expenditure and value added (Table 1). Understanding this result requires exploring some additional indicators and comparing these to the original expenditure results (which indicate the sectors of the economy receiving the initial spending).

Figure 5 is a matrix plot, designed to reveal trade-offs between different indicators. The segments in the bottom-right quadrant (Greece, Germany and 'medium-spending') are the ones which perform best in both indicators as they have a lower than average water consumption and higher than average value added per USD. In contrast, the segments in the top-right 
quadrant ('high-spending' and Russia) perform worst across both indicators, with higher than average water use and lower than average value added per USD.

The good performance of Greece, Germany and the 'medium-spending' segment can be explained by their higher proportion of spending in sectors with high value added coefficients and low water use coefficients (see Appendix). The higher than average proportion of spending on accommodation, transport and other expenditure categories is a characteristic shared by all three segments. The 'medium-spending' segment does have lower spending on accommodation, which gives it a lower ratio of value added to USD spent compared to the other segments. An analysis of the IO sectors receiving the bulk of the initial or first-round expenditure on accommodation, transport and other expenditure categories reveals that these are all sectors with high value added in relation to output such as retail trade, telecommunications, real estate and maintenance of motor vehicles. These are also incidentally sectors with low to moderate water consumption coefficients (see Appendix) allowing the segments to remain below average water use.

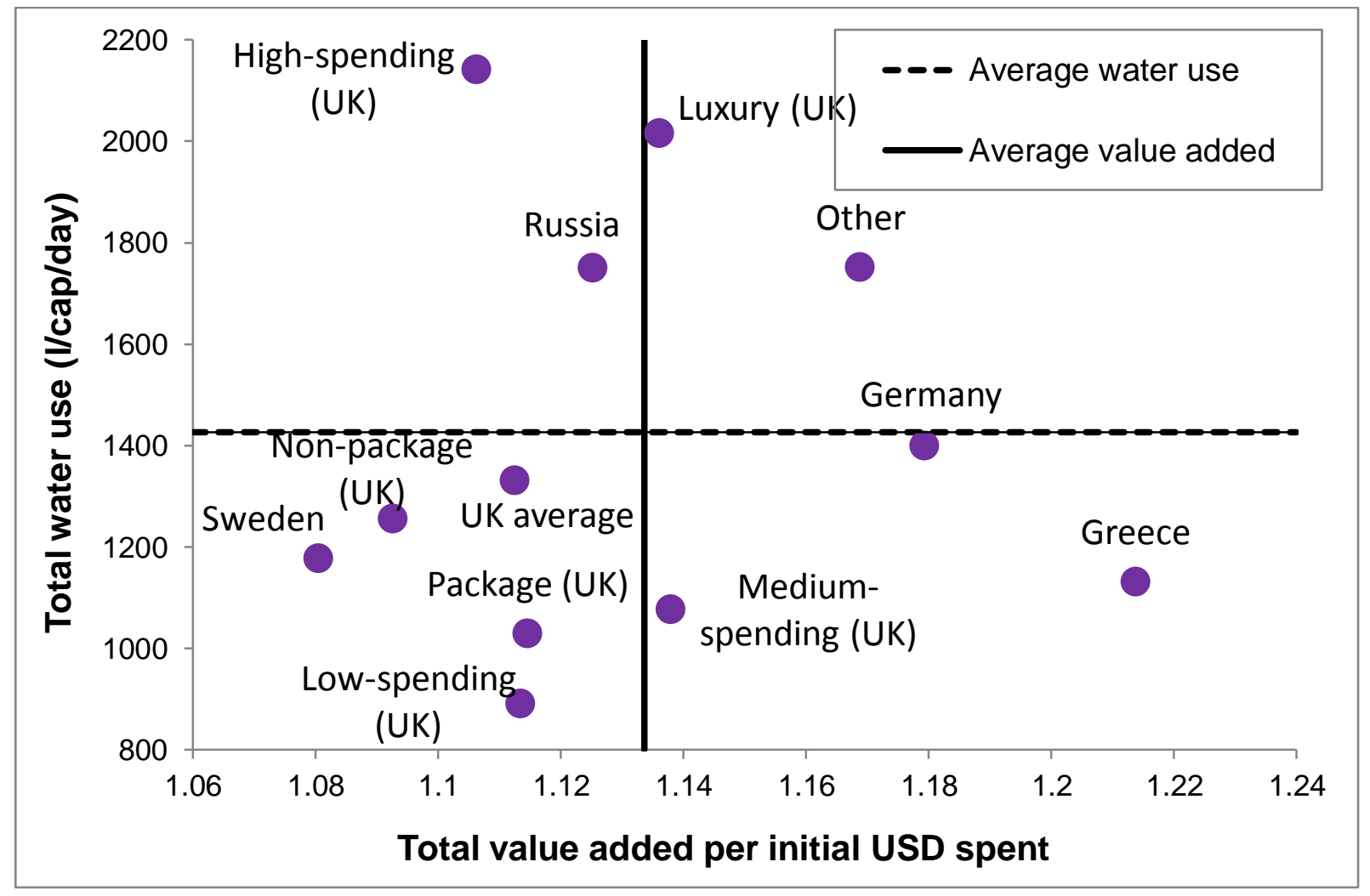

Figure 5 Value added per USD of tourist expenditure (in basic prices) and water use (1/cap/day) in relation to the corresponding values of the average inbound tourist for 2007.

Figure 6 shows the relation between water use and the number of jobs supported directly and indirectly for every million USD spent. Greece and Germany perform well again and are joined by the UK (average) and the 'low-spending' segment. The presence of Greece and Germany coupled with the absence of the 'medium-spending' segment suggest that the spending on 
accommodation (spread between the retail, hotel and restaurant, and agricultural sectors) contributes significantly to employment. The UK (average) and 'low-spending' segments spend a higher percentage of their overall expenditure on food, drinks and tobacco, which are also associated with high employment contribution. Their water use remains low mainly because their overall spending is lower than average.

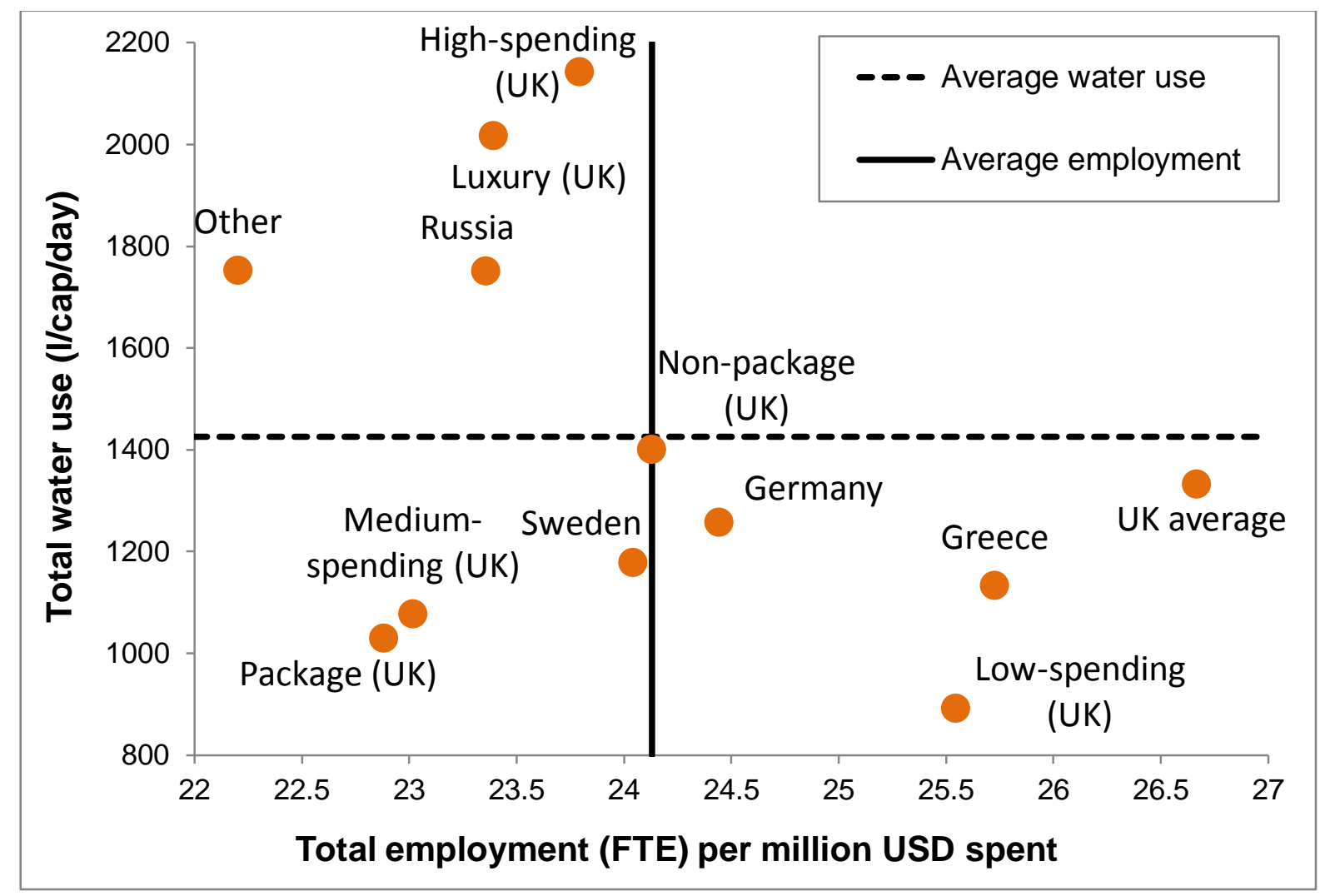

Figure 6 Total (direct and indirect) employment (jobs FTE) generated per one million USD of expenditure and water use (1/cap/day) compared to the average inbound tourist for 2007.

\section{Discussion}

\section{Direct water use}

The results support the findings of previous studies where indirect water use dominates over direct water use for all kinds of tourism consumption (Cazcarro et al., 2014; Gössling et al., 2012a; Lundie et al., 2007; Yang, Hens, De Wulf, \& Ou, 2011). However, direct water use still constitutes an important percentage of overall water use for the more budget end of the market (up to 35\% for package tourists). For destinations that rely predominantly on mass tourism, solutions to increase on-site efficiency in tourism establishments may provide the most immediate and cost-effective way to reduce water use intensity (Becken et al., 2013; Gössling et al., 2012a; UNEP-UNWTO, 2012).

Indirect and total water use and origin of water 
Summing up water use across all inbound tourism segments reveals that tourism consumption was directly and indirectly responsible for around $21 \mathrm{MCMs}$ (million $\mathrm{m}^{3}$ ) or $10 \%$ of the total water use in Cyprus in 2007. Direct water use by tourism was around 4\%, (WDD, 2011), meaning that the supply chain used up around $6 \%$ of the country's annual water resources to satisfy approximately 2.5 million tourists. When imported water is also considered, the total is around 34 MCMs. The results highlight the global dimension of tourism-related water consumption (Cazcarro et al., 2014). Imports of agricultural products allow Cyprus to 'save' more than half of the water that would have been needed if all products which cater for tourism had been produced locally. Some key solutions for minimising tourist water use actually lie outside the tourism domain (for instance, by increasing water use efficiency in agriculture). Imports of water-intensive crops like fruit and vegetables may increase as water becomes scarcer on the island.

\section{Water use intensity and sustainable yield implications}

Adopting the perspective of Lundie et al. (2007) and Becken \& Simmons (2008), tourism management initiatives should aim to reduce water use intensity from all segments. In the context of the present study, this could be interpreted as exploring ways to push segments towards the 'coveted' bottom-right quadrant in Figures 5 and 6. In principle, this is an attractive concept because the matrix graph may allow a prioritisation of management efforts to achieve a higher yield. Segments in the bottom-right quadrant already have lower than average water use so for some (for example "package", "low" and Sweden) it may be a case of trying to increase expenditure by the right amount (as too much may then drive water use up) to 'push' them into the bottom-right quadrant. For the ones in the top-right quadrant, it may be a case of seeking higher water efficiency in accommodation or encouraging behavioural changes.

Segments with an otherwise low per capita contribution to value added and employment (such as Germany or Greece), have a low water use impact as well as a high contribution to employment and value added with respect to their expenditure. Boosting expenditure and pursuing more arrivals from these market segments (or other segments with similar characteristics) may represent a sustainable strategy and provide a preferable option to boosting expenditure elsewhere through diversification and attempts to target the higher end of the market. These findings support the arguments made in previous studies with respect to the environmental and economic advantages of maintaining a healthy mass tourism product in Mediterranean destinations like Cyprus (Ayres, 2000; Farsari, Butler, \& Prastacos, 2007; Ioannides \& Holcomb, 2003; Sharpley, 2003).

A choice to import more agricultural products in order to save local water is not likely to have a substantial impact on value added as the contribution of the agricultural sector to GDP is low, even when accounting for multiplier effects (see Appendix). Nevertheless, the agricultural sector does have a relatively high contribution to employment with respect to the number of 
jobs it sustains directly and indirectly (see Appendix), and one of the attractions of a tourist destination can often be the sampling of local agricultural produce by tourists. Negative impacts on employment carry social implications and need to be evaluated. Investigating such trade-offs in detail (for specific goods and services) requires a disaggregated EEIO model, the need for which is further discussed below.

\section{Framework appraisal and future research avenues}

Performing segmentation as part of an integrated segmentation-yield framework has several advantages compared to previous work. Firstly, the outputs of the segmentation procedure are at the right level of detail and in the necessary classification to perform yield estimates. Secondly, it allows for an in-depth appreciation of the differences between diverse tourist groups and a better understanding of the reasons behind dissimilarities in economic impact and/or water use. This knowledge can subsequently provide guidance on how to improve the performance of different segments (Becken \& Simmons, 2008; Lundie et al., 2007). Thirdly, the details with respect to type of accommodation, area, and time of year of the visits allow an accurate determination of direct water use using secondary data. The method allows spatially and temporally weighted direct water use estimates for any given market segment. Fourthly, in this framework, segmentation research which does not typically trace the impacts of tourism spending is combined with more elaborate yield measures to compare the economic contribution of groups established on the basis of their total expenditure. This also allows for an assessment of the expenditure categories which contribute most to different measures of economic impact.

The present framework potentially allows for estimating the performance of different types of tourism across numerous economic and environmental indicators. Research shows that different indicators of economic contribution often result in a different ranking of segments (Dwyer \& Forsyth, 2008; Lundie et al., 2007; Pratt, 2012). Further indicators of economic yield as well as other environmental indicators (carbon emissions, waste, land use) may be investigated using a similar model setup to reveal trade-offs and synergies between policy objectives in any destination. Sun \& Pratt (2014) propose the use of a weighted aggregation of criteria. The emphasis here was on water use, value added and employment, as these are key variables of concern in water scarce Mediterranean destinations.

Using actual and projected trends in numbers for different tourist types, the framework could be used to evaluate the water use and economic impacts of changes in the tourism sector. For instance, this could include increases in arrivals from certain countries or increased numbers of golf tourists. Moreover, research based on surveys of tourists and hotel and restaurant 
managers could explore why different tourist types have different preferences, to better understand consumption patterns associated with higher water use intensity.

\section{Limitations and uncertainty - improving estimates}

A number of sources of uncertainty originate from the use of the EEIO model. This includes limitations related to the use of EEIO such as linearity and homogeneity, sector aggregation, and the 'domestic technology assumption', in addition to issues specific to the present framework.

Firstly, on the issue of linearity and homogeneity, IO analysis does not take into account economies of scale in production as it assumes a fixed relationship between sector output and its inputs. As the representation of flows is linear, a doubling in output requires a doubling of inputs, thus ignoring dynamic effects such as behavioural change and response to changes in price (Murray \& Lenzen, 2010). The same linear proportionality applies to estimating environmental impacts whereby impact of a particular product or service is linearly correlated to expenditure.

Secondly, in almost every EEIO study there is a need for more disaggregated economic and environmental impact estimates which would allow for investigating the effects of changes in demand for certain products. The negative impacts arising from sector aggregation have been stressed in previous tourism research (Briassoulis, 1991; Lundie et al., 2007). As indirect water use is closely associated to food consumption (Gössling et al., 2012; Hadjikakou et al., 2013; Sun \& Pratt, 2014), it is imperative that the analysis is carried out at a level of disaggregation capable of producing specific recommendations for hotel buffets or restaurant menus in order to reduce water use intensity for different kinds of tourism consumption. This would complement a growing literature on the critical issue of sustainable food consumption in the tourism context (Gössling \& Hall, 2013; Pratt, 2013).

The third inherent assumption of the present framework is the DTA. In reality, the water intensity of imports may differ from that of domestic products. It is therefore widely acknowledged that multi-region input-output (MRIO) models account for trade in a more realistic manner (Lenzen et al., 2004; Wiedmann, 2009), which implies that studies employing the DTA tend to be associated with larger errors in terms of estimated environmental impacts. Since Cyprus is a water scarce country which tends to import most of its products from European countries that are less water scarce and have higher production efficiencies, it is likely that the DTA assumption leads to a higher embedded water content for imports than in reality (this point was previously made in reference to Australia in Lenzen \& Foran, 2001).

DTA is justified firstly because of a lack of disaggregated water coefficients for other countries that trade with Cyprus. Additionally, it is consistent with Renault's (2002) 'savings' perspective which assumes that the volume water embedded in imported products is the volume of water that would have been consumed if Cyprus had produced the goods domestically. This is 
commonly employed in EEIO water studies focusing on single countries (see, for example, Lenzen \& Foran, 2001; Sun \& Pratt, 2014; Zhao et al., 2010) and where identifying the origin and impact of water originating from abroad falls outside the scope of the study. Nonetheless, the EEIO framework described in this study can certainly accommodate an MRIO model as a future refinement (see Cazcarro et al., 2014).

In terms of study-specific limitations, two important issues need to be acknowledged. Firstly, assumptions were made in estimating the original WIOD IOT based on trade data, National Account data and price base conversions with incomplete data (Timmer et al., 2012). The internal structure of the IOT is produced by simulation and there was no previous official IOT to test it against. Secondly, there is no standardised procedure for allocating initial tourism expenditure into the IO classifications. Briassoulis (1991) refers to this issue as the 'assumed sectoral distribution of tourist spending'. Deciding which sectors are likely to receive the initial injection of expenditure as given in the tourism survey or the TSAs involves a significant degree of subjectivity (Jones \& Munday, 2007). The sector matching/disaggregation procedure is admittedly a source of error however, based on previous studies, this is to be expected when using aggregated passenger survey and TSA data to produce final demand vectors compatible with the more disaggregated IOT structure (Jones \& Munday, 2007; Lundie et al., 2007).

Quantitative assessment of uncertainty in IO models involves identifying uncertainty in the source data and its effect on the final result. This tends to reveal that errors from over- or under- reporting from the multitude of data sources normally used to construct IOTs are random and result in a reduced final error once all the sources are aggregated (Murray \& Lenzen, 2010). Lenzen (2000) has estimated that errors in organisation studies lie in the $10-20 \%$ range whereas economy-wide studies have potentially lower error margins. The water consumption results obtained for residents of Cyprus based on the framework outlined in this study are similar to those from previous work (Arto, Genty, Rueda-Cantuche, Villanueva, \& Andreoni, 2012; Mekonnen \& Hoekstra, 2011; Steen-Olsen, Weinzettel, Cranston, Ercin, \& Hertwich, 2012), implying that the water use multipliers and the IO structure are producing sensible results.

\section{Conclusions}

Minimising the water use impact of tourism is certainly desirable, but in a competitive industry any water savings should ideally not compromise potential economic benefits to the receiving country. The primary aim of the study was to deliver a methodological framework which allows estimates of water use intensity for a variety of tourist types. The use of EEIO ensures that both environmental and economic impacts throughout the supply chain of tourism are captured, which allows for an appreciation of trade-offs and synergies using several indicators. The framework developed here also integrates a segmentation procedure that allows for comparisons between tourist market segments, as well for accurate direct water use estimates 
for any sub-segment of the sample. No previous study has performed such in-depth analysis of water use in relation to economic impact at a tourism destination.

The secondary aim of the study was to test the ability of the framework to generate insightful context-specific results. The findings from the Cyprus case study reveal significant variations in total water use (from around 900 to 21501 per capita daily) as well as in the relative ratios of direct and indirect water use between segments, owing mainly to their diverse spending patterns. Although higher-spending segments appear to have the lowest water use intensity because their overall spending compensates for their water use, several low-spending segments appear to offer high value added and employment contribution with respect to their expenditure and water use. These findings caution against seeing diversification as a panacea in tourism management, at a time when Cyprus, like other mature destinations, appears to be investing towards the luxury end of the market.

Nonetheless, tourism is highly diverse, and so is the higher-end of the market. It is likely that some tourists willingly pay higher prices for higher quality products with lower environmental impact. Sustainably run higher-end resorts, could, in theory, outperform cheaper establishments in terms of direct and indirect water, energy and other resource uses. Ultimately, it is perhaps preferable to accept that it is difficult to define an optimal tourist type (Becken \& Simmons, 2008). Tourists will always come in an assortment of different market segments and there is no 'one-size-fits-all' management approach for reducing water use (and other environmental) impacts. Thorough quantification, offered by approaches such as the one developed here, could help understand and minimise economic-environmental trade-offs with the potential to inform the development of bespoke management interventions for different forms of tourism.

\section{Please cite article as:}

Hadjikakou, M., Miller, G., Chenoweth, J., Druckman, A. \& Zoumides, C. (2015): A comprehensive framework for comparing water use intensity across different tourist types, Journal of Sustainable Tourism, DOI: 10.1080/09669582.2015.1044753.

Published online: 30 Jul 2015

To link to this article: http://dx.doi.org/10.1080/09669582.2015.1044753 


\section{References}

Adamou, A., \& Clerides, S. (2009). Tourism, development and growth: International evidence and lessons for Cyprus. Cyprus Economic Policy Review, 3(2), 3-22.

Allan, J. A. (1998). Virtual water: A strategic resource global solutions to regional deficits. Ground Water, 36(4), 545-546.

Arto, I., Genty, A., Rueda-Cantuche, J. M., Villanueva, A., \& Andreoni, V. (2012). Global resources use and pollution, volume 1 / production, consumption and trade (1995-2008). Luxembourg: Joint Research Centre (JRC), European Commission.

AUTHORS (DATE). Re-thinking the economic contribution of tourism: Case study from a Mediterranean island. JOURNAL .

Ayres, R. (2000). Tourism as a passport to development in small states: Reflections on Cyprus. International Journal of Social Economics, 27(2), 114-133.

Becken, S., \& Patterson, M. (2006). Measuring national carbon dioxide emissions from tourism as a key step towards achieving sustainable tourism. Journal of Sustainable Tourism, 14(4), 323-338.

Becken, S., Rajan, R., Moore, S., Watt, M., \& McLennan, C. (2013). White paper on tourism and water. Brisbane: EarthCheck Research Institute.

Becken, S., \& Simmons, D. (2008). Using the concept of yield to assess the sustainability of different tourist types. Ecological Economics, 67(3), 420-429.

Becken, S., Simmons, D., \& Frampton, C. (2003). Segmenting tourists by their travel pattern for insights into achieving energy efficiency. Journal of Travel Research, 42(1), 48-56.

Bramwell, B. (2004). Mass tourism, diversification and sustainability in southern Europe's coastal regions. In B. Bramwell (Ed.), Coastal mass tourism: Diversification and sustainable development in southern Europe (pp. 1-31). Clevedon: Channel View Publications.

Briassoulis, H. (1991). Methodological issues: Tourism input-output analysis. Annals of Tourism Research, 18(3), 485-495.

Cazcarro, I., Hoekstra, A. Y., \& Sánchez Chóliz, J. (2014). The water footprint of tourism in Spain. Tourism Management, 40, 90-101.

Cole, S. (2014). Tourism and water: From stakeholders to rights holders, and what tourism businesses need to do. Journal of Sustainable Tourism, 22(1), 89-106.

CYSTAT. (2012). National economic accounts 2011. Nicosia, Cyprus: Cyprus Statistical Service/Press and Information Office. 
CYSTAT. (2014). Cyprus statistical service homepage. Retrieved April 12, 2014 from http://www.mof.gov.cy/mof/cystat/statistics.nsf/index gr/index gr?OpenDocument.

Dolnicar, S. (2008). Market segmentation in tourism. In A. Woodside, \& D. Martin (Eds.), (pp. 129-150). Cambridge: CABI.

Druckman, A., \& Jackson, T. (2009). The carbon footprint of UK households 1990-2004: A socioeconomically disaggregated, quasi-multi-regional input-output model. Ecological Economics, 68(7), 2066-2077.

Dwyer, L., \& Forsyth, P. (2008). Economic measures of tourism yield: What markets to target? International Journal of Tourism Research, 10(2), 155-168.

Dwyer, L., Forsyth, P., \& Dwyer, W. (2010). Tourism economics and policy. Bristol: Channel View Publications.

Essex, S., Kent, M., \& Newnham, R. (2004). Tourism development in Mallorca: Is water supply a constraint? Journal of Sustainable Tourism, 12(1), 4-28.

Farsari, Y., Butler, R., \& Prastacos, P. (2007). Sustainable tourism policy for Mediterranean destinations: Issues and interrelationships. International Journal of Tourism Policy, 1(1), 58-78.

Gleick, P. H. (2003). Water use. Annual Review of Environment and Resources, 28(1), 275-314.

Gössling, S. (2001). The consequences of tourism for sustainable water use on a tropical island: Zanzibar, Tanzania. Journal of Environmental Management, 61(2), 179-191.

Gössling, S., \& Hall, C. M. (2013). Sustainable culinary systems. In S. Gössling, \& C. M. Hall (Eds.), Sustainable culinary systems: Local foods, innovation, tourism and hospitality (pp. 3-44). Abingdon: Routledge.

Gössling, S., Peeters, P., Ceron, J. P., Dubois, G., Patterson, T., \& Richardson, R. B. (2005). The eco-efficiency of tourism. Ecological Economics, 54(4), 417-434.

Gössling, S., Peeters, P., Hall, C. M., Ceron, J. P., Dubois, G., Lehmann, L. V., \& Scott, D. (2012a). Tourism and water use: Supply, demand, and security. an international review. Tourism Management, 33(1), 1-15.

Hadjikakou, M., Chenoweth, J., \& Miller, G. (2012). Water and tourism. In. A. Holden \& D.A. Fennell (Eds.), The Routledge Handbook of Tourism and the Environment (pp. 435-446), Abingdon, Oxon: Routledge.

Hadjikakou, M., Chenoweth, J., \& Miller, G. (2013). Estimating the direct and indirect water use of tourism in the eastern Mediterranean. Journal of Environmental Management, 114, 548-556.

Hochstrat, R. \& Kazner, C. (2009). Case study report Cyprus: Flexibility in coping with water stress and integration of different measures. TECHNEAU, European Commission. 
Hoekstra, A. Y. (2003). Virtual water trade. Delft, The Netherlands: IHE Delft.

Hof, A., \& Schmitt, T. (2011). Urban and tourist land use patterns and water consumption: Evidence from Mallorca, Balearic Islands. Land use Policy, 28(4), 792-804.

Ioannides, D., \& Holcomb, B. (2003). Misguided policy initiatives in small-island destinations: Why do up-market tourism policies fail? Tourism Geographies, 5(1), 39-48.

Jones, C., \& Munday, M. (2007). Exploring the environmental consequences of tourism: A satellite account approach. Journal of Travel Research, 46(2), 164.

Kasim, A., Gursoy, D., Okumus, F., \& Wong, A. (2014). The importance of water management in hotels: A framework for sustainability through innovation. Journal of Sustainable Tourism, 22(7), 1090-1107.

Lenzen, M. (2000). Errors in conventional and Input-Output-based Life-Cycle inventories. Journal of Industrial Ecology, 4(4), 127-148.

Lenzen, M., \& Foran, B. (2001). An input-output analysis of Australian water usage. Water Policy, 3(4), 321-340.

Lenzen, M., Pade, L. L., \& Munksgaard, J. (2004). CO2 multipliers in multi-region input-output models. Economic Systems Research, 16(4), 391-412.

Leontief, W. (1936). Quantitative input and output relations in the economic systems of the United States. The Review of Economic Statistics, 18(3), 105-125.

Leontief, W. (1970). Environmental repercussions and the economic structure: An input-output approach. The Review of Economics and Statistics, 52(3), 262-271.

Ludwig, R., Roson, R., Zografos, C., \& Kallis, G. (2011). Towards an inter-disciplinary research agenda on climate change, water and security in southern Europe and neighboring countries. Environmental Science \& Policy, 14, 794-803.

Lundie, S., Dwyer, L., \& Forsyth, P. (2007). Environmental-economic measures of tourism yield. Journal of Sustainable Tourism, 15(5), 503-519.

Mekonnen, M. M., \& Hoekstra, A. Y. (2011). National water footprint accounts: The green, blue and grey water footprint of production and consumption. Delft, the Netherlands: UNESCO-IHE Institute for Water Education.

Miller, R. E., \& Blair, P. D. (2009). Input-output analysis: Foundations and extensions (2nd ed.). Cambridge: Cambridge University Press.

Munday, M., Turner, K., \& Jones, C. (2013). Accounting for the carbon associated with regional tourism consumption. Tourism Management, 36, 35-44. 
Murray, J., \& Lenzen, M. (2010). Introduction to input-output analysis. In J. Murray, \& R. Wood (Eds.), The sustainability practitioner's guide to input-output analysis (pp. 3-22). Champaign, Ill: Common Ground Publishing.

Northcote, J., \& Macbeth, J. (2006). Conceptualizing yield: Sustainable tourism management. Annals of Tourism Research, 33(1), 199-220.

OECD. (2001). Glossary of statistical terms. Retrieved May 10, 2012, Source: http://stats.oecd.org/glossary/detail.asp?ID=1184.

ONS. (2013). The relationship between gross value added (GVA) and gross domestic product (GDP). Retrieved 15 October, 2013 from http://www.ons.gov.uk/ons/guidemethod/method-quality/specific/economy/national-accounts/gva/relationship-gva-andgdp/gross-value-added-and-gross-domestic-product.html.

Pratt, S. (2012). Tourism yield of different market segments: A case study of Hawaii. Tourism Economics, 18(2), 373-391.

Pratt, S. (2013). Minimising food miles: Issues and outcomes in an ecotourism venture in fiji. Journal of Sustainable Tourism, 21(8), 1148-1165.

Proops, J. L. R., Faber, M., \& Wagenhals, G. (1993). Reducing CO2 emissions: A comparative inputoutput study for Germany and the UK. Heidelberg: Springer-Verlag Berlin.

Reid, L. J., \& Reid, S. D. (1997). Traveler geographic origin and market segmentation for small island nations: The Barbados case. Journal of Travel \& Tourism Marketing, 6(3-4), 5-21.

Renault, D. (2003). Value of virtual water in food: Principles and virtues Value of Water Research Report Series No.12. Delft, the Netherlands: UNESCO-IHE.

Rico-Amoros, A. M., Olcina-Cantos, J., \& Sauri, D. (2009). Tourist land use patterns and water demand: Evidence from the western Mediterranean. Land use Policy, 26(2), 493-501.

Salma, U., \& Heaney, L. (2004). Proposed methodology for measuring yield. Tourism Research Report (the Journal of Tourism Research Australia), 6(1), 73-81.

Savvides, L., Dörflinger, G., \& Alexandrou, K. (2001). The assessment of water demand of Cyprus. FAO Land and Water Development Division.

Sharpley, R. (2003). Tourism, modernisation and development on the island of Cyprus: Challenges and policy responses. Journal of Sustainable Tourism, 11(2-3), 246-265.

Steen-Olsen, K., Weinzettel, J., Cranston, G., Ercin, A. E., \& Hertwich, E. G. (2012). Carbon, land, and water footprint accounts for the European Union: Consumption, production, and displacements through international trade. Environmental Science E Technology, 46, 1088310891. 
Sun, Y. (2014). A framework to account for the tourism carbon footprint at island destinations. Tourism Management, 45, 16-27.

Sun, Y., \& Pratt, S. (2014a). The economic, carbon emission, and water impacts of Chinese visitors to Taiwan: Eco-efficiency and impact evaluation. Journal of Travel Research, DOI: 10.1177/0047287513517420.

Timmer, M., Erumban, A. A., Francois, J., Genty, A., Gouma, R., Los, B., . . de Vries, G. J. (2012). The world input-output database (WIOD): Contents, Sources and methods. Source: http://www.wiod.org: WIOD.

Tortella, B. D., \& Tirado, D. (2011). Hotel water consumption at a seasonal mass tourist destination. the case of the island of Mallorca. Journal of Environmental Management, 92(10), 2568-2579.

Tourism Concern. (2012). Water equity in tourism: A human right, a global responsibility. London: Tourism Concern. Source: http://www.tourismconcern.org.uk/uploads/Water-EquityTourism-Report-TC.pdf.

UN DESA. (2007). Indicators of sustainable development: Guidelines and methodologies. New York: United Nations Department of Economic and Social Affairs.

UNEP-UNWTO. (2012). Tourism in the green economy - background report. Madrid: UNWTO.

UNESCO. (2009). Monitoring progress in the water sector: A selected set of indicators. New York: United Nations.

UNWTO. (2007). Handbook on tourism market segmentation - maximising marketing effectiveness. Madrid: World Tourism Organization and European Travel Commission.

UNWTO. (2013a). Message by UNWTO secretary-general taleb rifai. Retrieved 06 November, 2013, Source: http://wtd.unwto.org/en/content/unwtosg.

UNWTO. (2013b). President of Cyprus - tourism key for the country. Retrieved September 10, 2013, Source: http://media.unwto.org/en/press-release/2013-06-05/president-cyprustourism-key-country.

UNWTO. (2013c). UNWTO Tourism Highlights, 2013 edition. Madrid: World Tourism Organization (UNWTO).

WDD. (2011). Water demand estimates. In Ministry of Agriculture, Natural Resources and Environment. Nicosia: Cyprus Water Development Department (WDD).

Wiedmann, T. (2009). A review of recent multi-region input-output models used for consumption-based emission and resource accounting. Ecological Economics, 69(2), 211222. 
Wiedmann, T., Minx, J., Barrett, J., \& Wackernagel, M. (2006). Allocating ecological footprints to final consumption categories with input-output analysis. Ecological Economics, 56(1), 28-48.

WTTC. (2014a). Economic Impact 2013: Cyprus. London: World Travel and Tourism Council (WTTC).

WTTC. (2014b). Economic Impact of Travel \& Tourism 2014 annual update: Summary. London: World Travel and Tourism Council (WTTC).

Yang, M., Hens, L., De Wulf, R., \& Ou, X. (2011). Measuring tourist's water footprint in a mountain destination of northwest Yunnan, China. Journal of Mountain Science, 8(5), 682693.

Zhao, X., Yang, H., Yang, Z., Chen, B., \& Qin, Y. (2010). Applying the Input-Output Method to Account for Water Footprint and Virtual Water Trade in the Haihe River Basin in China. Environmental Science \& Technology, 44(23), 9150-9156. 
Table 1. Economic impact indicators for all tourist segments in current basic USD prices for 2007.

\begin{tabular}{|c|c|c|c|c|c|c|c|}
\hline Segment & $\begin{array}{c}\text { Daily } \\
\text { expenditure }\end{array}$ & $\begin{array}{c}\text { Total } \\
\text { Value Added }\end{array}$ & $\begin{array}{c}\text { Employment } \\
\text { (per } 1000 \\
\text { tourists) }\end{array}$ & $\begin{array}{c}\text { Final } \\
\text { demand }\end{array}$ & Total Output & $\begin{array}{l}\text { VA per USD } \\
\text { spent }\end{array}$ & $\begin{array}{c}\text { Employment } \\
\text { per USD } \\
\text { million }\end{array}$ \\
\hline & $(\$)$ & $(\$)$ & FTE & $(\$)$ & $(\$)$ & - & FTE \\
\hline Average Tourist & 106.09 & 120.27 & 2.56 & 146.93 & 201.92 & 1.13 & 24.13 \\
\hline Germany & 100.28 & 118.26 & 2.58 & 144.14 & 198.27 & 1.18 & 25.73 \\
\hline Greece & 79.87 & 96.94 & 2.13 & 117.85 & 162.36 & 1.21 & 26.67 \\
\hline UK & 98.47 & 109.54 & 2.30 & 133.94 & 183.81 & 1.11 & 23.36 \\
\hline Russia & 131.84 & 148.34 & 3.17 & 181.33 & 249.13 & 1.13 & 24.04 \\
\hline Sweden & 88.73 & 95.87 & 1.97 & 117.25 & 160.63 & 1.08 & 22.20 \\
\hline Other & 130.35 & 152.35 & 3.33 & 185.96 & 256.26 & 1.17 & 25.55 \\
\hline Low spenders & 63.43 & 70.62 & 1.46 & 86.12 & 117.92 & 1.11 & 23.02 \\
\hline Medium spenders & 78.59 & 89.43 & 1.87 & 108.93 & 149.38 & 1.14 & 23.79 \\
\hline High spenders & 167.56 & 185.36 & 3.92 & 227.04 & 311.85 & 1.11 & 23.39 \\
\hline Luxury & 157.10 & 178.48 & 3.84 & 218.33 & 300.34 & 1.14 & 24.44 \\
\hline Non-package & 90.91 & 99.32 & 2.08 & 121.77 & 167.19 & 1.09 & 22.88 \\
\hline Package & 71.10 & 79.25 & 1.64 & 96.70 & 132.48 & 1.11 & 23.07 \\
\hline
\end{tabular}


Appendix - Direct and total water use and economic contribution coefficients based on sectoral output and the Leontief inverse matrix.

\begin{tabular}{|c|c|c|c|c|c|c|c|}
\hline & ECONOMIC SECTOR & $\begin{array}{l}\text { Direct water } \\
1 / \text { USD }\end{array}$ & $\begin{array}{l}\text { Total water } \\
\text { 1/USD }\end{array}$ & $\begin{array}{l}\text { Direct VA } \\
\text { VA/Output }\end{array}$ & $\begin{array}{c}\text { Total VA } \\
\text { VA/Output }\end{array}$ & $\begin{array}{l}\text { Direct Emplovment } \\
\text { \# of jobs/1M Output }\end{array}$ & $\begin{array}{l}\text { Total Emplovment } \\
\text { \# of jobs/1M Output }\end{array}$ \\
\hline 1 & Agriculture, Hunting, Forestry and Fishing & 152.600 & 167.100 & 0.452 & 0.688 & 18.574 & 23.942 \\
\hline 2 & Mining and Quarrving & 10.800 & 11.000 & 0.563 & 0.775 & 5.739 & 8.728 \\
\hline 3 & Food, Beverages and Tobacco & 1.500 & 19.600 & 0.275 & 0.663 & 7.316 & 16.219 \\
\hline 4 & Textiles and Textile Products & 0.200 & 2.400 & 0.377 & 0.665 & 22.091 & 29.150 \\
\hline 5 & Leather, Leather and Footwear & 0.200 & 1.100 & 0.485 & 0.757 & 14.399 & 19.935 \\
\hline 6 & Wood and Products of Wood and Cork & 0.200 & 1.100 & 0.372 & 0.659 & 11.602 & 18.645 \\
\hline 7 & Pulp, Paper, Paper, Printing and Publishing & 0.200 & 0.400 & 0.402 & 0.689 & 9.635 & 14.950 \\
\hline 8 & Chemicals and Chemical Products & 0.600 & 0.900 & 0.356 & 0.586 & 7.943 & 12.304 \\
\hline 9 & Rubber and Plastics & 0.200 & 0.400 & 0.372 & 0.567 & 10.626 & 14.269 \\
\hline 10 & Other Non-Metallic Mineral & 3.700 & 5.500 & 0.307 & 0.673 & 4.821 & 10.363 \\
\hline 11 & Basic Metals and Fabricated Metal & 0.200 & 0.400 & 0.337 & 0.436 & 8.635 & 10.203 \\
\hline 12 & Machinerv, Nec & 0.100 & 0.200 & 0.357 & 0.517 & 9.814 & 12.677 \\
\hline 13 & Electrical and Optical Equipment & 0.100 & 0.300 & 0.223 & 0.447 & 5.280 & 9.495 \\
\hline 14 & Transport Equipment & 0.200 & 0.300 & 0.391 & 0.623 & 10.064 & 14.278 \\
\hline 15 & Manufacturing, Nec; Recycling & 0.200 & 0.700 & 0.368 & 0.627 & 12.921 & 18.855 \\
\hline 16 & Electricity, Gas and Water Supply & 0.100 & 0.200 & 0.428 & 0.446 & 1.800 & 1.984 \\
\hline 17 & Construction & 0.000 & 0.800 & 0.459 & 0.717 & 10.033 & 14.522 \\
\hline 18 & Sale, Maintenance and Repair of Motor & 0.000 & 0.100 & 0.563 & 0.864 & 15.981 & 18.425 \\
\hline 19 & Wholesale Trade and Commission Trade & 0.000 & 0.100 & 0.607 & 0.802 & 12.377 & 16.036 \\
\hline 20 & Retail Trade & 0.000 & 0.100 & 0.635 & 0.886 & 22.018 & 24.870 \\
\hline 21 & Hotels and Restaurants & 0.000 & 4.200 & 0.522 & 0.792 & 15.292 & 20.673 \\
\hline 22 & Inland Transport & 0.000 & 0.000 & 0.524 & 0.694 & 19.452 & 22.255 \\
\hline 23 & Water Transport & 0.000 & 0.100 & 0.477 & 0.538 & 13.607 & 14.629 \\
\hline 24 & Air Transport & 0.000 & 0.300 & 0.249 & 0.471 & 3.421 & 7.455 \\
\hline 25 & Other Supporting and Auxiliary Transport & 0.000 & 0.200 & 0.597 & 0.766 & 9.556 & 12.147 \\
\hline 26 & Post and Telecommunications & 0.000 & 0.000 & 0.629 & 0.864 & 5.773 & 8.363 \\
\hline 27 & Financial Intermediation & 0.000 & 0.000 & 0.764 & 0.933 & 8.970 & 11.521 \\
\hline 28 & Real Estate Activities & 0.000 & 0.200 & 0.732 & 0.917 & 1.067 & 4.422 \\
\hline 29 & Renting of $\mathrm{M} \& \mathrm{Eq}$ and Other Business & 0.000 & 0.100 & 0.669 & 0.890 & 12.317 & 15.773 \\
\hline 30 & Public Admin and Defence; Compulsory Social & 0.000 & 0.100 & 0.693 & 0.802 & 12.861 & 14.601 \\
\hline 31 & Education & 0.000 & 0.700 & 0.874 & 0.942 & 17.642 & 18.663 \\
\hline 32 & Health and Social Work & 0.000 & 0.200 & 0.665 & 0.767 & 14.355 & 16.350 \\
\hline 33 & Other Communitv, Social and Personal & 0.000 & 0.200 & 0.663 & 0.879 & 28.121 & 31.456 \\
\hline
\end{tabular}


Appendix 2 - TSA expenditure breakdown, price-base conversion and import ratio per sector.

\begin{tabular}{|c|c|c|c|c|}
\hline Sector Coc Sector & Final demand ratio & Price base conversion (from Cyprus SUTs - Eurostat 2012) & Ratio local & Ratio imported \\
\hline AtB Agriculture, Hunting, Forestry and Fishing & 1 & 0.897303949 & 0.672591879 & 0.327408121 \\
\hline C Mining and Quarrying & 1 & 0.999357349 & 0.295084051 & 0.704915949 \\
\hline $15 t 16$ Food, Beverages and Tobacco & 0.552670286 & 0.759798472 & 0.455223795 & 0.544776205 \\
\hline $17 t 18$ Textiles and Textile Products & 0.007778641 & 0.63325072 & 0.020410857 & 0.979589143 \\
\hline 19 Leather, Leather and Footw ear & 0.006768681 & 0.511049657 & 0.088885824 & 0.911114176 \\
\hline 20 Wood and Products of Wood and Cork & 0.033107471 & 0.812748712 & 0.867209114 & 0.132790886 \\
\hline $21+22$ Pulp, Paper, Paper, Printing and Publishing & 0.169292441 & 0.766752957 & 0.787166472 & 0.212833528 \\
\hline 23 Coke, Refined Petroleum and Nuclear Fuel & 0 & 0.838247708 & 0 & 1 \\
\hline 24 Chemicals and Chemical Products & 0.006808641 & 0.731379248 & 0.019039598 & 0.980960402 \\
\hline 25 Rubber and Plastics & 0.04633069 & 0.786246574 & 0.552076247 & 0.447923753 \\
\hline Other Non-Metallic Mineral & 0.067214907 & 0.85233669 & 0.83941919 & 0.16058081 \\
\hline 27 t28 Basic Metals and Fabricated Metal & 0.063525042 & 0.863612638 & 0.530079322 & 0.469920678 \\
\hline 29 Machinery, Nec & 0.002500315 & 0.784586551 & 0.026503034 & 0.973496966 \\
\hline $30+33$ Eectrical and Optical Equipment & 0.001773585 & 0.770511835 & 0.031022882 & 0.968977118 \\
\hline 34t35 Transport Equipment & 0.000286085 & 0.657197153 & 0.000532289 & 0.999467711 \\
\hline 36t37 Manufacturing, Nec; Recycling & 0.041943214 & 0.71323166 & 0.193620988 & 0.806379012 \\
\hline E Eectricity, Gas and Water Supply & 1 & 0.980371897 & 0.991556504 & 0.008443496 \\
\hline F Construction & 1 & 1 & 0.837397321 & 0.162602679 \\
\hline 50 Sale, Maintenance and Repair of Motor Vehicles and Motorcycles; Retail Sale of Fuel & 0.06723313 & 1.34661771 & 0.997019625 & 0.002980375 \\
\hline 51 Wholesale Trade and Commission Trade, Except of Motor Vehicles and Motorcycles & 0.175510741 & 5.619054396 & 0.965030258 & 0.034969742 \\
\hline 52 Retail Trade, Except of Motor Vehicles and Motorcycles; Repair of Household Goods & 0.192512197 & 64.03497542 & 0.981697048 & 0.018302952 \\
\hline H Hotels and Restaurants & 0.631977062 & 0.975201296 & 0.999507976 & 0.000492024 \\
\hline 60 Inland Transport & 0.271300117 & 1 & 0.931537962 & 0.068462038 \\
\hline 61 Water Transport & 1.47739E-06 & 1 & 0.000837221 & 0.999162779 \\
\hline 62 Air Transport & 0.193053063 & 1 & 0.772323531 & 0.227676469 \\
\hline 63 Other Supporting and Auxiliary Transport Activities; Activities of Travel Agencies & 0.084280813 & 1 & 0.153767962 & 0.846232038 \\
\hline 64 Post and Telecommunications & 0.451364531 & 0.998693688 & 0.896075811 & 0.103924189 \\
\hline J Financial Intermediation & 0.262526405 & 0.983155255 & 0.933551028 & 0.066448972 \\
\hline 70 Real Estate Activities & 0.703557819 & 0.993344741 & 0.999669065 & 0.000330935 \\
\hline 71174 Renting of M\&Eq and Other Business Activities & 0.033915776 & 1 & 0.910944931 & 0.089055069 \\
\hline L Public Admin and Defence; Compulsory Social Security & 0.059356895 & 1 & 0.948673927 & 0.051326073 \\
\hline M Education & 0.234249527 & 1 & 0.99662495 & 0.00337505 \\
\hline N Health and Social Work & 0.262578212 & 1 & 0.990489336 & 0.009510664 \\
\hline O Other Community, Social and Personal Services & 0.372781177 & 1 & 0.966792475 & 0.033207525 \\
\hline \multirow{8}{*}{ P Private Households with Employed Persons } & 0.071034188 & 1 & 1 & 0 \\
\hline & \multicolumn{2}{|c|}{ TSA Expenditure categories (from Cyprus 2007 TSAs - CYSTAT) } & & \\
\hline & \multicolumn{2}{|c|}{ Industry/manufacturing } & & \\
\hline & \multirow{2}{*}{\multicolumn{2}{|c|}{$\begin{array}{l}\text { Retails and restaurants } \\
\text { Transport and communications }\end{array}$}} & & \\
\hline & & Transport and communications & & \\
\hline & \multicolumn{2}{|r|}{ Business } & & \\
\hline & \multirow{2}{*}{\multicolumn{2}{|c|}{$\begin{array}{l}\text { Community, social \& personal services } \\
1 \text { Already disaggregated in TSA - No further disaggregation ne }\end{array}$}} & & \\
\hline & & & ecessary & \\
\hline
\end{tabular}




\section{Please cite article as:}

Hadjikakou, M., Miller, G., Chenoweth, J., Druckman, A. \& Zoumides, C. (2015): A comprehensive framework for comparing water use intensity across different tourist types, Journal of Sustainable Tourism, DOI: 10.1080/09669582.2015.1044753.

Published online: 30 Jul 2015

To link to this article: http://dx.doi.org/10.1080/09669582.2015.1044753 